\title{
CEU
}

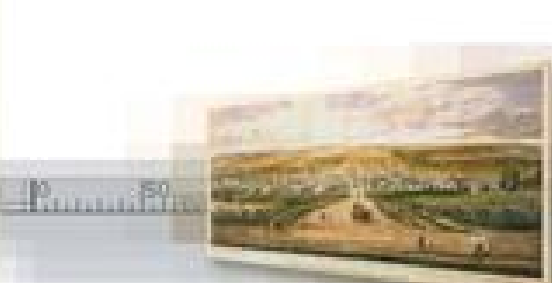

* Trabajo realizado por la Biblioteca Digital de la Universidad CEU-San Pablo

- Me comprometo a utilizar esta copia privada sin finalidad lucrativa, para fines de investigación y docencia, de acuerdo con el art. 37 de la M.T.R.L.P.I. (Modificación del Texto Refundido de la Ley de Propiedad Intelectual del 7 julio del 2006) 


\section{Those Who Left and Those Who Stayed Behind: Explaining Emigration from the Regions of Spain, 1880-1914}

\section{BLANCA SÁNCHEZ-ALONSO}

Spain's contribution to the "New Emigration" differed from that of other Southern European countries in that it was oriented to Latin America far more than to the United States, in that it reached massive proportions only after 1900 , and in that the various Spanish provinces varied greatly in their emigration rates. Differences in wealth, income, literacy, urbanization, and migratory tradition best explain these international and interprovincial differences.

From the 1880s to the First World War more than 3 million Spaniards 1 departed for foreign destinations. The majority of these emigrants settled in Latin America: in 1914 Spaniards were the largest immigrant group in Cuba, the second-largest in Argentina and Uruguay, and the third-largest in Brazil. Surprisingly, though, the case of Spain is missing from the classical studies on European emigration, an impoverishing oversight that this study will seek to redress. We will find many similarities with other "New Emigration" countries such as Italy and Portugal, but also important differences. Three of the most distinctive features of Spanish emigration are a constant and persistent orientation towards Latin American countries, an extremely high concentration of emigrants in the first decade of the twentieth century, and a large variance in emigration rates across regions.

Was Spanish emigration different from other "New Emigration" countries? Did the low level of income per capita prevent higher rates of emigration from Spain? What accounts for the remarkable variation in emigration rates across regions, particularly the very modest emigration from the south, a region otherwise so similar to Italy's high-emigration Mezzogiorno? Did the differences across Spanish regions result from tradition and persistence, or from poverty and lack of information? These are the main questions addressed in this article. The first section surveys the main characteristics of Spanish emigration, and asks why it was focused on a few Latin American

The Journal of Economic History, Vol. 60, No. 3 (Sept. 2000). The Economic History Association. All rights reserved. ISSN 0022-0507.

Blanca Sánchez-Alonso is Associate Professor of Economic History, Universidad San Pablo, Dpto. de Economia, Julián Romea, 23, 28003 Madrid, Spain. E-mail: blanca@ceu.es.

I gratefully acknowledge comments and suggestions by Patrick K. O'Brien, Kevin O'Rourke, David S. Reher, Leandro Prados de la Escosura, James Simpson, and participants at the Oxford Economic History Seminar. I have also benefited from helpful comments of three anonymous referees and the editor of this JOURNAL. Graham Jones and Heath Pearson did an excellent job with the English text. This article was written while visiting at St Antony's College, Oxford. Financial support was provided by the Spanish Ministry of Education and Culture, PF 9705253090. 
countries. We then compare Spain with Italy and Portugal and present a time-series model of Spanish emigration. There follows a discussion of different hypotheses for regional patterns of emigration. These hypotheses are then tested within the framework of a provincial emigration model. Conclusions follow.

\section{WHY WERE SPANISH EMIGRANTS DIFFERENT?}

According to recent research, international labor markets were segmented along a Latin versus non-Latin divide. ${ }^{1}$ To no nation does this generalization better apply than to Spain, more than 90 percent of whose emigrants went to Argentina, Brazil, Cuba, and Uruguay (Table 1). ${ }^{2}$ By contrast, between 1900 and 1913 less than 2 percent landed in the United States, the major destination for European emigration as a whole. This pattern has led Timothy Hatton and Jeffrey Williamson to argue that Spanish emigrants thereby missed an opportunity to achieve faster real wage growth. ${ }^{3}$

Why was Spanish emigration so overwhelmingly focused on Latin America? Language, religion, and cultural identity have often been invoked as explanations. ${ }^{4}$ Comparing Australia and Argentina, two competing destinations for European emigrants, Alan Taylor argues that a stronger influx of Latin emigrants to the River Plate was driven in large part by the cultural proximity between Argentina and Southern Europe. ${ }^{5}$ It might also be due to the existence of old colonial links, such as those with Cuba; but it is more difficult to trace those links in countries such as Argentina or Uruguay, which had been independent for generations. ${ }^{6}$ It can also be suggested that Cuba, where Spaniards enjoyed a privileged position until 1898, acted as a substitute for the United States. Spanish emigrants may have preferred a Spanish colony to the American market, such that they never developed migratory chains or acquired sufficient knowledge of employment opportunities in the United States.

\footnotetext{
'Taylor, "Mass Migration": and Hatton and Williamson, Age of Mass Migration, chap. 6.

${ }^{2}$ There was also a seasonal emigration to Algeria, with a downward trend over the years 1880 to 1914.

${ }^{3}$ Hatton and Williamson, Age of Mass Migration, chap. 2.

${ }^{4}$ Gould, "European Inter-Continental Emigration: Patterns and Causes." For example, emigrants from Orense, in Galicia, chose Brazil as a country of destination in greater numbers than did their counterparts from any other Spanish province. Proximity to Northern Portugal, a region with high emigration rates to Brazil, and language, very close to Portuguese, seem to be the most plausible explanations for this preference.

${ }^{5}$ Taylor, "Mass Migration," pp. 110-11.

-After Argentinian independence Spaniards, when not considered enemies, were considered undesirable strangers. In fact some of the early Spanish immigrants in Buenos Aires pretended to be Portuguese or French because of native hostility to them (Moya Cousins and Strangers, pp. 336-39). However, Moya also suggests that migratory traditions lay dormant and then are revitalized once mass migration recommences.
} 
TABLE 1

SPANISH EMIGRATION, 1888-1913, BY MAJOR DESTINATION (percentage of total overseas emigration)

\begin{tabular}{lccr}
\hline & $1888 / 90$ & $1904 / 06$ & $1911 / 13$ \\
\hline Argentina & 46.40 & 42.65 & 66.40 \\
Cuba & 30.17 & 29.02 & 19.07 \\
Brazil & 7.84 & 16.72 & 4.79 \\
Others & 15.59 & 11.61 & 9.74 \\
\hline
\end{tabular}

Source: Sánchez-Alonso, Cousas, appendix A.3.

Destination-country policy might also have been a powerful explanation of the destination choices of Spanish emigrants. Taylor states that Latin emigrants were excluded from Australia's high-wage labor market "as a matter of policy choice," but the opposite often held true in Latin America. In Brazil, the state of São Paulo financed the arrival of immigrants during the great coffee boom of the late nineteenth century. In 1911 more than 70 percent of Spanish immigrants to São Paulo arrived with a subsidized passage. ${ }^{7}$ The Argentinian government also subsidized emigration from Europe for a short period from 1888 to 1890 . Almost 45 percent of those passages were distributed in Spain, which explains the spike in emigration rates in 1889 (Figure 1). A single province, Málaga, received more than 10,000 subsidized passages in that year, subsequently returning to its very low emigration rates to Argentina. Argentina quickly abandoned this costly subsidy because immigrants arrived in large numbers without any official help. The Spanish government itself tried, unsuccessfully, to direct emigration to Cuba during the nineteenth century, with the objective of "whitening" the colony; but emigrants continued to flood into Cuba after independence, and particularly during the sugar boom of the 1920s. Thus culture, language, and old colonial links, not policy, seem to explain Spanish preference for Latin America. Whereas Italians defied cultural and linguistic barriers in heading to North America, Spaniards did not.

Spanish emigration policy was halfhearted at best. Most politicians and intellectuals disapproved of emigration, and deeply regretted that Spain was thereby losing population, "the most important wealth of a nation."8 For contemporaries, emigration was "a very serious illness, an epidemic," reprehensible especially if it preempted compulsory military service. Members of the élite thought that Spanish emigrants were ignorant, illiterate, poor and backward, in contrast with the industrious Italians. The most outrageous explanations for Spanish emigration, such as the Galician spirit of adventure and the lack of patriotism of Castilians, can be found in the contemporary

\footnotetext{
${ }^{7}$ Klein, "Integración social y económica" p. 449.
}

'Botella, Problema de la emigración, p. 186. 


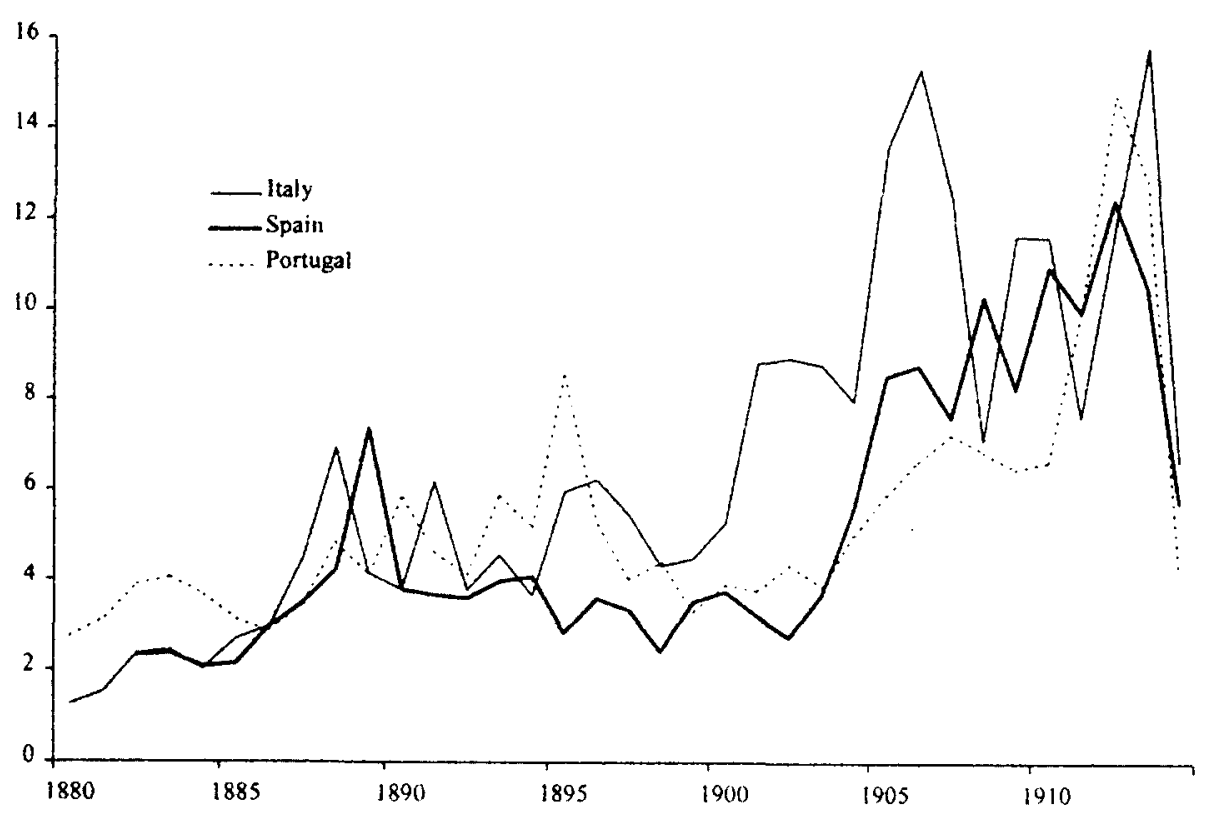

FIGURE 1

GROSS EMIGRATION FROM SOUTHERN EUROPE, 1880-1914

(per thousand inhabitants)

Sources: For Spain, Sánchez-Alonso, Causas, appendix A3: for Italy, Rosoli, Secolo, appendix; for Portugal, Baganha, Portuguese Emigration.

literature. ${ }^{9}$ This negative assessment informed the very restrictive Emigration Law of 1907. Furthermore, massive Spanish emigration coincided with a period of national depression and political crisis after the loss of Cuba and Puerto Rico; emigration was therefore viewed as symptomatic of national decline. ${ }^{10}$

Spanish emigrants were typically young and single, like other European emigrants. As Hatton and Williamson have argued, the benefits of emigrating were greater for single, unskilled, young adults than for the population at large. ${ }^{11}$ According to Spanish statistics, men accounted for more than 70 percent of all emigrants between 1882 and 1914, although female participation increased over time. Male emigration was higher to Cuba (more than 80 percent) than to Brazil, where 45 percent of Spanish immigrants were women. The explanation lies in the Brazilian policy of subsidizing family immigration. Most emigrants seem to have been young adults. According to a 1914 Argentinian population census, 32 percent of Spanish immigrants were concentrated in the 20 to 29 age group, more than double

\footnotetext{
${ }^{9}$ Consejo Superior de Emigración, Emigración española.

${ }^{10}$ Sánchez-Alonso, Causas, chap. 2.

"Hatton and Williamson, Age of Mass Migration, chap. 2.
} 
that group's share in Spain's total population (15 percent). Most Spanish emigrants traveled alone. However, family emigration to countries such as Argentina and Uruguay increased over time. In 1895 only 17 percent of Spanish immigrants entering Argentina were family members, compared to more than 56 percent of the Italians, but by 1913 the percentage of Spanish families had increased to 43 percent, similar to the Italian figure (42 percent). ${ }^{12}$ In Brazil, too, the proportion of families was higher among Spanish arrivals than Italians. ${ }^{13}$

Spanish emigration reports also shed light on the occupational structure of emigrants. Agricultural workers formed the largest group of Spanish emigrants, almost 60 percent in $1911 / 13 .{ }^{14}$ Since Spain was an agrarian country, this occupational structure is not surprising. ${ }^{15}$ Spanish emigration records do not provide information about literacy until 1925, but according to an Argentinian census only 26 percent of Spaniards over the age of seven living in Argentina were illiterate in 1914, compared to 50 percent of the total Spanish population in 1910. In Italy illiteracy ran at 38 percent in 1911, a rate similar to that of Italians living in Argentina. ${ }^{16}$ It might be the case that the Argentinian economy attracted more literate immigrants than did other destinations, but according to Cuban statistics more than 80 percent of Spanish immigrants between 1903 and 1927 were literate. And of the few Spanish emigrants landing in the United States in the $1890 \mathrm{~s}$, 90 percent were literate. ${ }^{17}$ Given the image of Spanish emigrants as backward these data may seem surprising; but they are not so when compared to literacy rates in the Spanish regions of high emigration, especially the north coast. In 1910, 66 percent of Galician males aged 16 to 20 were literate, and the corresponding figure for Asturian males was more than 80 percent. High rates of literacy could then be related to high rates of emigration from the north coast and northern Castile. Higher levels of both education and emigration in the north of Spain might explain the choice of destination among Spanish emigrants. Given the advantage of language, they had more to gain in Argentina or

\footnotetext{
${ }^{12}$ Sánchez-Alonso, Inmigración española, chap. 4.

${ }^{13}$ Klein, "Integración social y económica," p. 441.

${ }^{14}$ Most of these appear to have been proletarians. According to Argentinian immigration data, for example, 38 percent of Spanish immigrants were "wage laborers" (jornaleros), whereas only 12 percent were described as "farmers" (agricultores). By contrast, Italians entering Argentina in that year were 32 percent farmers and 18 percent laborers (Sánchez-Alonso. Inmigración española, chap. 4). In Brazil, 79 percent of Spanish immigrants were agricultural workers (Klein, "Integración social y económica," p. 452).

is In 1887, 72 percent of the active male population was employed in agriculture. That fraction decreased to 65 percent by $1900 / 10$, but almost 50 percent of the active population was still in agriculture in 1930 (Simpson, Spanish Agriculture, p. 18).

${ }^{16}$ Sánchez-Alonso, Inmigración española, chap. 3.

${ }^{17}$ Republica de Cuba, Inmigración. The major contrast is with Brazil, where, between 1908 and 1936, 79 percent of Spanish immigrants over age 7 were illiterate (Klein, "Integración social y económica," p. 452). For the United States, see Cipolla, Literacy and Development, table 17.
} 
Cuba than in the United States. Similarly, the proportion of skilled workers among Italians, for whom Spanish was much easier to learn than English, was much higher in Buenos Aires than in New York. ${ }^{18}$ Literate emigrants from the north of Spain had much to gain by going to Latin America. Illiterates from the Spanish South, who could have gone to the United States as Southern Italians did, had low emigration rates, possibly because they were so illiterate that they did not receive enough information about foreign markets. In any case, it seems that literacy was important in determining both the propensity and the destination of Spanish emigration.

According to this picture, Spaniards were not so different from other Southern European emigrants, except in their preference for Latin American destinations. Spanish emigration also presents a chronology very similar to Italy's or Portugal's, except for the low rates in the 1890s (Figure 1).

\section{AGGREGATE TRENDS IN SPANISH EMIGRATION}

Spanish emigration statistics, based on passenger lists, were first compiled in 1882 by the Instituto Geográfico y Estadístico. These summary statistics analyze emigration flows by country of destination, sex, age, occupation, and province of last residence. They understate the true level of emigration, which included clandestine departures and less distant destinations. ${ }^{19}$ But these statistical flaws are unlikely to undermine the conclusion that emigration rates rose significantly in the early twentieth century. Figure 1 shows the gross rate of emigration from Italy, Spain, and Portugal. There are two similar periods in the three series: the late 1880 s, which show a rising trend, and the period 1904 to 1913 , which witnessed a more sharply rising trend and an overall peak. But Spanish emigration trends differ from Italian and Portuguese trends during the 1890 s and the early 1900s, when the Spanish series leveled off while Italian and Portuguese emigration started to rise dramatically. ${ }^{20}$ There is also a secular trend of rising return migration (Figure 2), though these data should be treated with care in light of very substantial underenumeration. Immigration statistics from the main receiving countries show the same trends and fluctuations.

\footnotetext{
"Baily, "Italian Immigrants"; and Klein, "Integración social y económica." However, according to Hatton and Williamson (Age of Mass Migration, table 6.9) there is no evidence in the Italian case to support the view that regions with higher literacy went to Latin America while those with lower literacy went to the United States. And indeed the Canary Islands, which also experienced high rates of emigration to Latin America was not a region of high literacy.

${ }^{19}$ After 1914 very substantial emigration to France was included, but the volume of emigration to Europe before that year remains unknown. For a new estimate of Spanish emigration series see Sánchez-Alonso, Causas, chap. 2.

${ }^{20}$ I have argued elsewhere (Sánchez-Alonso, "European Emigration") that Spanish emigration was so low in the 1890 s, namely because of the depreciation of the Spanish currency in those years.
} 


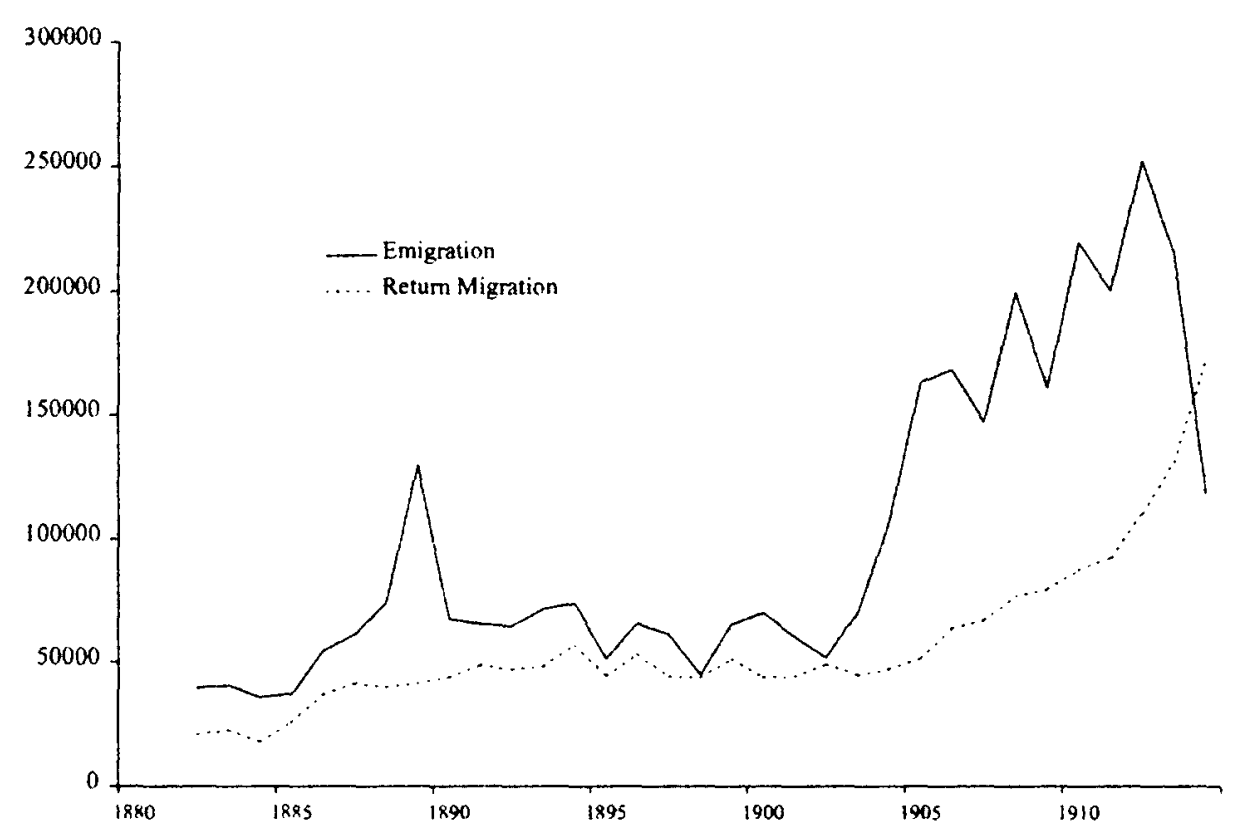

FIGURE 2

SPANISH EMIGRATION AND RETURN MIGRATION, 1882-1914

Source: Sánchez-Alonso, Causas, appendix A3.

Italian emigration rates increased at 6.5 percent per annum between 1880 and 1899 , and then at 4.5 percent from 1900 to 1913 , while its Spanish counterpart increased at 2.2 percent and 12 percent over those same periods. Why did this acceleration take place in the early years of the twentieth century? Hatton and Williamson have argued that rising European emigration was driven mainly by population growth, nascent industrialization, and the rising emigrant stock itself. ${ }^{21}$ Italy, Spain, and Portugal shared underlying fundamentals that contributed to the surge in emigration: incipient industrialization, and rising expatriate populations abroad. For the Italian case, Riccardo Faini and Alessandra Venturini have developed the idea, originally suggested by Brinley Thomas, that rising per capita income was a powerful impetus to emigration. ${ }^{22} \mathrm{By}$ releasing the poverty constraint for a large group of potential emigrants, economic growth in Italy led to a surge in the emigration rates despite the declining income gap between Italy and destination countries. Was this also the case in Spain? Is it possible that emigration rates in the final decades of the nineteenth century were depressed by low per

${ }^{21}$ Hatton and Williamson, Age of Mass Migration, chap. 2.

${ }^{22}$ Faini and Venturini, "Italian Emigration," pp. 86-88; see also Thomas, Migration and Economic Growth, p. 117. But Hatton and Williamson (Age of Mass Migration, table 6.3) reject the hypotheses that rising real wages in Italy were an important cause of emigration. 
TABLE 2

REGRESSION RESULTS: SPANISH INTERCONTINENTAL EMIGRATION, 1882-1914 (dependent variable: gross emigration rate)

\begin{tabular}{lrc}
\hline Constant & -5.376 & $(-1.424)$ \\
Deviations from trend in Argentine construction output (lagged $t-1)$ & 0.393 & $(2.293)^{* *}$ \\
Wage ratio Argentina-Spain & 1.032 & $(2.908)^{* * *}$ \\
Spanish income per capita (lagged $t-2)$ & 1.672 & $(2.051)^{*}$ \\
Emigration rate (lagged $t-1)$ & 0.582 & $(6.060)^{* * *}$ \\
Rate of natural increase (lagged $t-20)$ & -0.403 & $(-1.878)^{*}$ \\
$R^{2}$ & 0.842 & \\
$R^{2}$ (adjusted) & 0.812 & \\
S.E. of regression & 0.232 & \\
Durbin-Watson & 2.005 & \\
$F$-statistic & 27.878 & \\
$N$ & 33 & \\
\hline
\end{tabular}

* = Significant at the 10 percent level.

** = Significant at the 5 percent level.

*** = Significant at the 1 percent level.

Notes: $t$-statistics are in parentheses. Independent variables are expressed in logs, except for deviations from trend in Argentine construction output which are indexed $(1913=100)$. Standard errors and covariance are White heteroskedasticity-consistent.

Sources: Gross emigration rates are from Sánchez-Alonso, Causas; Argentinian construction output is from Cortés Conde, Economia argentina: Wage ratios are from Williamson, "Evolution"; Spanish per capita income is from Prados de la Escosura. "Output and Expenditure"; Rates of natural increase are from Nicolau, "Población."

capita income? Conversely, was economic modernization after 1900 associated with rising emigration rates?

Table 2 presents a time-series regression model for Spanish emigration. The gross emigration rate, plotted in Figure 1, is the dependent variable. The regressor representing foreign economic conditions is the deviation from trend in Argentinian construction activity, a sector with high demand for unskilled labor, and one very sensitive to economic fluctuations. Per capita income in Spain is included in order to test whether Spanish emigration was income constrained, in which case rising per capita income would have increased emigration. Two classical variables in emigration studies, namely the wage gap (here, between Argentina and Spain) and the rate of natural increase, are also included. Finally, past emigration represents chain migration or the "family-and-friends" effect. Most of these variables are lagged to reflect the likelihood that developments at home and abroad affected emigration only with some delay.

Several conclusions can be drawn from Table 2 . The classical hypothesis of demographic forces driving emigration can be rejected in the Spanish case, a conclusion consistent with previous research. ${ }^{23} \mathrm{~A}$ boom in the natural rate of population increase two decades earlier was a powerful force pushing up early-twentieth-century emigration rates in both Italy and Portugal, but

${ }^{23}$ Hatton and Williamson, Age of Mass Migration, pp. 44-45, table 3.5. 
the Spanish case is quite distinct: rates of natural increase had been falling in Spain for two decades. Consequently, the demographic variable has a weakly negative association with emigration. The regression does however confirm that Spanish emigration was income-constrained. The per-capita income variable displays a positive sign and a significant coefficient, very much in line with the results obtained by Faini and Venturini for the Italian case. ${ }^{24}$ Given Spain's initial poverty, rising income per capita was positively associated with emigration because it allowed people to finance the move more easily. ${ }^{25}$ This result differs from the view of Hatton and Williamson, who reject this hypothesis for Spain, Portugal, and particularly for Italy. ${ }^{26}$

Economic conditions in Argentina were also a significant determinant of the migratory flow. The influence of construction activity is positive and significant, as is the wage differential between Spain and Argentina. Both variables yield results in line with research carried out for other countries. ${ }^{27}$ The lagged emigration rate is also positively related to emigration, as expected. Apparently, previous emigrants released the poverty constraint, financing the moves of others-although to a lesser extent than in Italy, because there were fewer of them.

To summarize: contrary to conventional wisdom, Spanish emigration was indeed income-constrained. Demographic forces were not a powerful explanation of emigration rates after the 1880 s, but Spanish emigrants seem to have responded to economic conditions abroad and to chain migration effects in much the same way as emigrants from the rest of Europe. It remains then to consider why Spanish emigration was so regionally concentrated.

\section{EXPLAINING REGIONAL EMIGRATION PATTERNS}

Although intercontinental emigration from Spain was relatively slight between 1880 and 1914 , in some regions it was a major demographic and socioeconomic phenomenon. Figures 3 and 4 show that emigration rates varied widely across the 49 Spanish provinces in both $1888 / 90$ and 1911/13. (These years were selected because they mark peaks in Spanish emigration flow; see Figure 1.) Between these dates the practice of emigration gradually diffused from its epicenters in the northwest and southeast: the mean provincial emigration rate rose from 3.8 to 9.5 per thou-

\footnotetext{
${ }^{24}$ Faini and Venturini, "Italian Emigration," p. 86.

${ }^{25}$ It can be argued that the real wage at home was a more relevant variable for potential emigrants than income per capita, but income per capita has been included given the superior reliability of the data. If instead of income per capita the real wage rate in Spain is included, the relationship with emigration is again positive, although less significant.

${ }^{26}$ Hatton and Williamson, Age of Mass Migration, pp. $105-06$.

${ }^{27}$ Hatton and Williamson, Age of Mass Migration, chaps. 5 and 6 (on Ireland and Italy).
} 


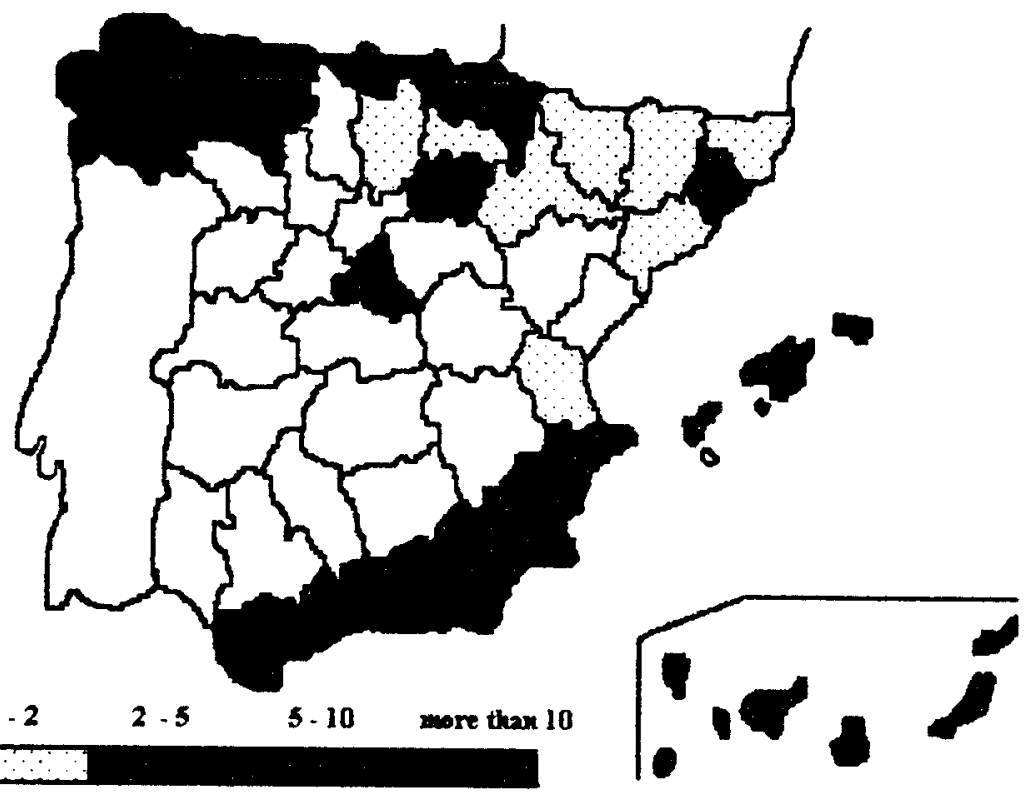

FIGURE 3

PROVINCIAL EMIGRATION RATES, 1888-1890

Note: Shadings are based on gross emigration rates per thousand population in each province in 1887 Source: Sánchez-Alonso, Causas, appendix A.6.

sand, while the coefficient of variation among provinces fell from 1.44 to $1.02 .^{28}$

Indeed, the extant records may well understate the diffusion of emigration through the Spanish interior. Data refer to the emigrant's last residence, not to the province of birth. In an age of transoceanic migration, this inevitably introduced a bias in favor of coastal provinces. ${ }^{29}$ But even according to the official records, in the peak years 1911/13 a large number of inland provinces showed high emigration rates. Antonio Machado, a well known Spanish poet, wrote in 1912 that one could not travel through Castile without hearing people talk of life overseas. ${ }^{30}$

The north coast, three provinces in the southeast, and the Canary Islands show the highest emigration rates in the nineteenth and twentieth centuries. Of the 25 provinces with highest emigration rates in 1911/13, 17 were in the north, five in the east and southeast, and four in the south (including the

\footnotetext{
24 The correlation between the series is 0.69 . Ravenstein ("Laws of Migration." p. 287) was the first to point out how "under normal circumstances migration movement will be gradual; it will go step by step from one region to another."

${ }^{29}$ By the eve of the First World War more than 40 percent of people embarking from Galician ports were not born in Galicia (López Taboada, Economia e población, p. 66).

${ }^{30}$ Machado, Campos de Castilla.
} 


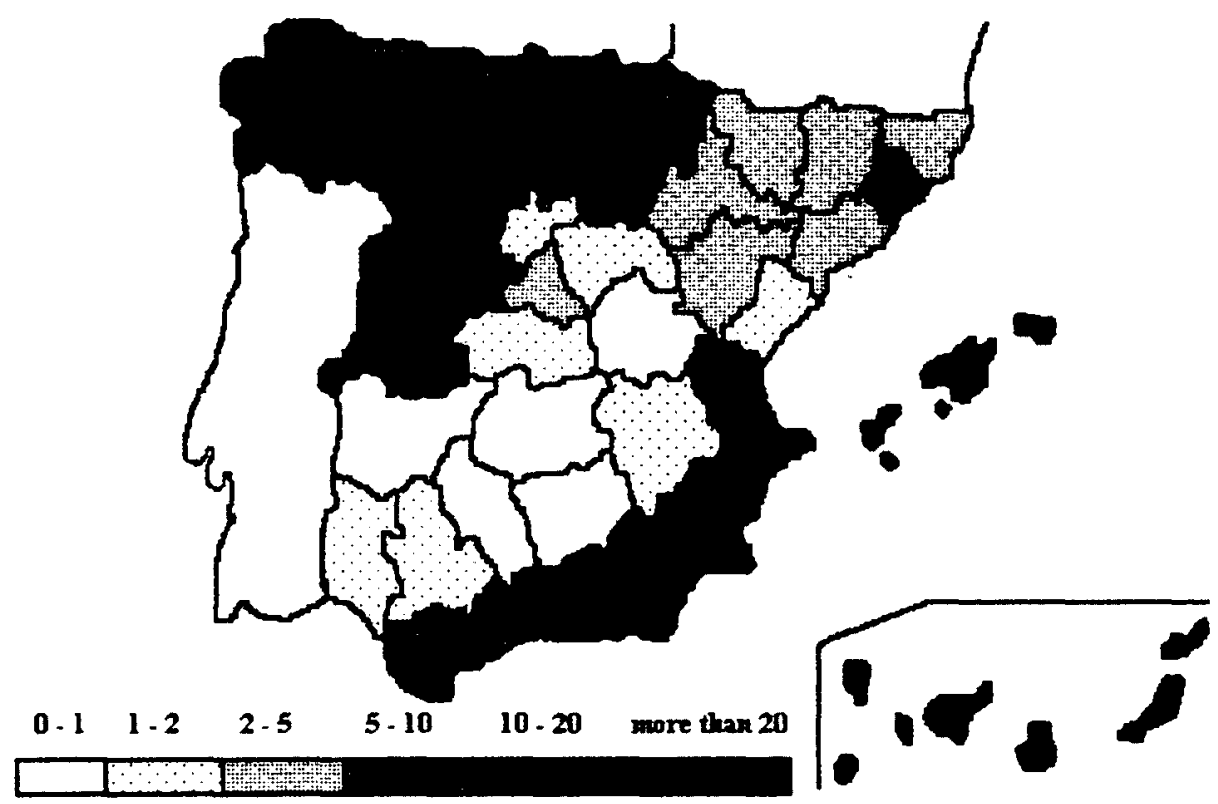

FIGURE 4

PROVINCIAL EMIGRATION RATES, 1911-1913

Note: Shadings are based on gross emigration rates per thousand population in each province in 1910. Source: Sánchez-Alonso, Causas, appendix A.6.

Canaries). However, migration from the east and the southeast was mainly seasonal, to Algeria. Western Andalusia, Extremadura, La Mancha and the interior showed the lowest emigration rates. Table 3 shows regional shares in emigration and in overall population.

Major regional contrasts existed in Spanish agriculture, due to differences in topography, climate, and soil. The interior and Andalusia, where summer droughts and high temperatures severely limited the choice of crops and livestock, were oriented mainly to cereals, legumes, olives, and vines. Output per hectare was much higher in the north and the Mediterranean, because of more favorable conditions for intensive livestock husbandry (north) and intensive crops, especially fruit and vegetables on the Mediterranean littoral. ${ }^{31}$

Why did people from Andalusia and the inland meseta-who, a priori, should have had as much or even more to gain from emigration-not leave Spain? How can we explain why so few day-laborers in the southern latifundia zone, who were allegedly living in miserable conditions, emigrated to Argentina or Cuba? In Southern Italy, high rates of emigration "were mainly due to poverty, a dominant agriculture, low urbanization, illiteracy,

${ }^{31}$ Simpson, Spanish Agriculture, chap. 2. 
TABLE 3

SPANISH GROSS EMIGRATION (1911/13) AND POPULATION (1910), BY REGION (percentage of total)

\begin{tabular}{lcc}
\hline & Emigration & Population \\
\hline Galicia & 29.62 & 10.32 \\
Castilla-León & 13.59 & 11.81 \\
Eastern Andalusia & 10.72 & 7.13 \\
North" & 10.39 & 8.3 \\
Valencia & 10.25 & 8.52 \\
Catalufia & 5.49 & 10.42 \\
Murcia & 4.02 & 3.07 \\
Western Andalusia & 3.6 & 12.01 \\
Canary Islands & 3.5 & 2.22 \\
Balearic Islands & 2.27 & 1.63 \\
Castilla-La Mancha & 2.11 & 12.07 \\
Navarre and La Rioja & 1.88 & 2.5 \\
Extremadura & 1.25 & 4.95 \\
Aragón & 1.23 & 4.76 \\
Spain & 100 & 100 \\
\hline
\end{tabular}

Asturias, Cantabria, and the Basque Country.

'Includes Madrid.

Sources: See the Appendix.

low wages and underdevelopment." 32 Since such conditions are also found in the Spanish south, why was emigration from this region not as common? And why did people from Castile not emigrate in the nineteenth century, but instead waited until the twentieth century to cross the Atlantic?

Although information spreads through several channels-for example migratory chains, family and friends, or return migration-literacy rates have been widely used as a proxy for the availability of information, and as predictors of social and geographical mobility. As John Gould has suggested for the Italian case, education and literacy, which mediated the flow of information, must have had an important influence on local emigration rates. ${ }^{33}$ It might be the case that educational backwardness in the Spanish South inhibited emigration; but it is also true that the Canary Islands, where literacy levels were quite low, had one of the highest emigration rates.

Some historians have argued that poverty suppressed emigration from many European regions. This seems to have been the case for Spanish emigration as a whole, as in Table 3 the variable for per-capita income is positively associated with emigration. From the regional point of view the central idea would be that the very poor Andalusians were unable to find resources to finance their exit. For an agricultural worker in Galicia and Asturias, the main migratory regions, the real cost of a passage to Buenos Aires increased from 153 working days in 1880/89 to 195 in

\footnotetext{
${ }^{32}$ Hatton and Williamson, Age of Mass Migration, p. 115.

${ }^{33}$ Gould, "European Intercontinental Emigration: The Role."
} 
$1892 / 1905$, due to depreciation of the peseta. ${ }^{34}$ But if low wages and illiteracy retarded emigration from the south and the interior, their effects must have been higher before 1900 than thereafter, as both incomes and literacy increased, and as pioneer emigrants presumably sent information and remittances.

The qualitative literature suggests many other determinants of regional emigration rates. Various scholars have argued for a strong link between demographic pressure and emigration across regions. ${ }^{35}$ Although we have found only weak evidence of demographic effects in the time-series analysis above, perhaps such forces are likelier to be revealed in the provincial crosssection. Indeed some of the provinces with high rates of natural increase, such as Galicia, did show the highest emigration rates.

In some historical cases-most famously, Britain after 1750-rapid population growth has been absorbed by domestic booms in agriculture or industry; but neither of these conditions obtained in Spain. Only Madrid, Barcelona, and Bilbao attracted any substantial internal migration, and as of 1910 only 9 percent of Spaniards lived outside their native province (up from 8 percent in 1887). Thus the lack of urban growth within Spain led to high levels of external migration. ${ }^{36}$

As in the Italian case, a number of historians have suggested important links between Spanish emigration and patterns of land tenure, which varied greatly from place to place. In some regions better opportunities to ascend the agricultural ladder generated temporary emigration as a strategy to acquire capital and become a landowner. According to Edward Malefakis, land ownership in Spain had two major characteristics: first, the predominance of either very large or small holdings, with few intermediate holdings just large enough to maintain comfortably a peasant family; and second, a marked regional difference in the distribution of the two extremes, smallholdings (minifundia) being found in the north and Old Castile, and large estates (latifundia) in the south and La Mancha. ${ }^{37}$ Farmers in the north had also to face strong demographic pressure, to which they responded in part through emigration, and in part by adjusting crop rotations to maximize yields ${ }^{38}$ The

\footnotetext{
${ }^{34}$ Calculated for the cheapest fare from Galician ports to Buenos Aires (Vázquez Gonzalez, "Emigración gallega," p. 93). Agricultural daily wages in Sánchez-Alonso, Causas, appendix. Average working days in Vandellós, "Richesse et le revenu," out of an average work year of 250 days. This excludes any allowances for foregone earnings during the trip, or for installation costs in the receiving country. For the effects of the peseta's depreciation on emigration see Sánchez-Alonso, "European Emigration."

${ }^{35}$ Since Nadal's pioneering work (Poblacion espantola) this has been a common explanation for, among others, López Taboada (Economia e población) for Galicia; Hernández Garcia (Emigración) for the Canary Islands; Vilar (Emigración) for the southeastern provinces; Pildain Salazar (Ir a América) for the Basque country; and Soldevilla ("Emigracion") for Santander.

${ }^{36}$ This was clearly suggested by Tortella, "Agriculture," p. 172.

${ }^{37}$ Malefakis, Agrarian Reform, p. 15.

34 Although geographically suiled to livestock farming, many farmers suffered from a shortage of capital and from the diseconomies of the minifundia (Simpson, Spanish Agriculture, chap. 1).
} 
problem for small and medium holders in Old Castile was not demographic pressure, but short leases of just two to three years.

For Italy, Dino Cinel has argued that in regions where large estates predominated, land was a nontradable good passed by inheritance within very few wealthy families. Emigration was therefore not a way up for the majority of landless workers. ${ }^{39}$ Instead, these workers developed a strong political reaction against big landowners. Similarly, the Andalusian latifundia created a large rural proletariat which developed, by the end of the century, a violent strain of anarchism. But despite the severe underdevelopment and poverty, emigration was rare in Andalusia, due perhaps to these institutional constraints on upward mobility. ${ }^{40}$ Indeed, emigration (mainly seasonal departures to Algeria) was higher from those Eastern Andalusian provinces where large estates were few. Furthermore, in areas of small farms--the north, León, and Old Castile-farmers had the possibility of selling or mortgaging their property to finance the cost of moving abroad, whereas landless workers in the south had to finance emigration from low wages. Historians have identified this relationship between land tenure and emigration for Portugal as well, where the northern smallholding zone had higher emigration rates than the Alentejo in the south. ${ }^{41}$ In the next section we will test whether this relationship holds true for Spain as well.

Another dimension of land tenure is inheritance, which may have had its own impact on emigration patterns. In particular, the practice of impartible inheritance - especially when conjoined with large family size-should have been associated with higher emigration rates, since this option was surely preferable to the life of a hometown hired hand. This point has been argued effectively for Ireland, but the Iberian case is less clear. ${ }^{42}$ José Moya points out that in some valleys in Navarre, where primogeniture prevailed, 28 percent of all emigrants to Buenos Aires were the first children of farm-owning families, who apparently preferred emigration to property, while Robert Rowland observed that in Portugal not only did excluded siblings emigrate, but sometimes also the inheritor, if he had to offer compensation. ${ }^{43}$ The peculiarities of the Castilian inheritance system may also have promoted emigration. Under Castilian law one-third of the estate (the so-called legitima) had to be equally divided among the heirs. The resulting inheritance was probably not enough to earn a living on, but it might provide the means

\footnotetext{
${ }^{39}$ Cinel, "Land Tenure Systems."

${ }^{40}$ Malefakis (Agrarian Reform, p. 201) points out that Andalusians finally began emigrating in the 1950s and 1960s, once Franco's regime had destroyed all hopes of agrarian reform.

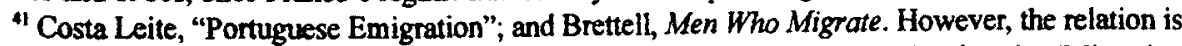
not so straightforward in Italy. See Sori, Emigrazione italiana, pp. 79-83; and Gabaccia, "Migration and Peasant Militance."

${ }^{42}$ Guinnane, Vanishing Irish; Fitzpatrick, Irish Emigration; and $O$ Gráda, "Primogeniture."

${ }^{43}$ Moya Cousins and Strangers, p. 30; Rowland, "Emigración, estructura y región," p. 142.
} 
to finance emigration..$^{44}$ The argument is important in so far as emigration was income constrained. Impartible inheritance systems and stem families were found in Spain in the North Atlantic, the Pyrenees, Cataluna, the Balearic Islands, and in some eastern provinces. Elsewhere the Castilian system predominated. ${ }^{45}$

Although suggestive, the Spanish literature on emigration has serious limitations. Historians present a full set of influences without determining quantitatively which among them were the most important; even simple bivariate analyses are wanting. Spanish emigration deserves a multivariate analysis, similar to those in existence for Ireland and Italy, in order to address these questions.

\section{A MODEL OF PROVINCIAL EMIGRATION}

This section explores the determinants of Spanish emigration by applying cross-sectional analysis to provincial emigration rates in 1888/90 and 1911/13. These years saw particularly high emigration (Figure 1). Indeed, in 1913 Spanish emigration rates were among the highest in Europe after Italy and Portugal, so it makes sense to ask why only a few Spanish regions contributed to the exodus. These years have been selected also for their proximity to the censuses of 1887 and 1910 , as these are the principal sources for the explanatory variables. Since more information is available for the twentieth century, the statistical analysis will concentrate on an explanation of provincial emigration rates on the eve of the First World War. Unfortunately, the province offers the lowest level of aggregation. The only way to analyze the determinants of emigration rates in the 49 provinces across the two census years is to create a panel data set with 98 observations in all. The sources and methods used to construct the variables are presented in the Appendix.

Demographic pressure is measured by the lagged rate of natural increase. Other structural characteristics are captured by the share of labor force in agriculture, agricultural output per worker, the proportion of the population living in towns of more than five thousand inhabitants, and trends in agricultural wages. ${ }^{46}$ Literacy has been included to proxy for the cost of information and the influence of education. It is assumed that, for any given year, increases in literacy rates are better indicators of the diffusion of information

\footnotetext{
"This has been clearly shown for the Basque country by Fernandez de Pinedo, "Movimientos migratorios vascos"; and for Asturias by Barreiro Mallon, "Ritmo, causas y consecuencias," p. 81.

${ }^{45}$ Lisón Tolosana, "Ethics of Inheritance."

${ }^{4}$ Real agricultural wages are not available for all Spanish provinces, but since price levels were not considerably different among provinces, nominal wages have been used. Since 1861 provincial price indexes show a well-integrated market, especially after 1900. See Ballesteros, "Estimación," tables 4 and 5 .
} 
than are the rates themselves. Spain's regions had long been characterized by wide differences in literacy, due probably to deeply rooted cultural values. For the historically less literate provinces (especially in the south), improvements over this period may have allowed potential emigrants to garner information about opportunities abroad.

The "family-and-friends" effect is difficult to measure. Net emigration rates by province are available only for the period 1887 to 1896 ; furthermore, the 1890 s do not represent a normal pattern for net emigration because many migrants returned from Argentina after the Baring crisis. Thus, to account for persistence effects and emigration tradition a new variable is used: the female/male ratio in the 50-to-60 age group for each province in the year 1887. The reason for this choice is that Spanish emigration was predominantly male throughout the nineteenth century, such that the imbalance between men and women within a province reflected past male emigration (assuming normal mortality differentials between the sexes). ${ }^{47}$ Thus, gender ratios for the 50-to-60 age group for 1887 could capture the outcome of migratory tradition. Emigrants of the $1850 \mathrm{~s}$ and 1860 s were the real pioneers, who presumably developed migratory chains that would overcome the income and informational constraints. Indeed, the provinces with lowest male/female ratios for this age group in 1887 were in Galicia and the Canary Islands, regions par excellence of emigration with traditions going back to the late eighteenth century. ${ }^{48}$

Turning to institutional factors, variations in inheritance systems are captured by a variable reflecting the predominance of partible or impartible inheritance. ${ }^{49}$ Differences in land tenure systems in each province have also been proxied. The 1920 population census provides data on the number of agricultural employers and workers in each province. The share of wage laborers in total agriculture labor force in each province has been used as a proxy for the concentration of land ownership. The assumption is that the higher the proportion of wage laborers, the more concentrated the ownership of land. Although the word patrón, as used in the census, is not the same as

\footnotetext{
${ }^{47}$ Return migration in the nineteenth century was much lower than in the twentieth, when transatlantic journeys became cheaper and easier (Figure 2); and although the gender ratio in a province might in theory be affected by internal migration, in fact interprovincial emigration was very low. In $1888 / 1900$ only ten of the 49 provinces had a positive migratory balance. See Mikelarena, "Movimientos migratorios," appendix. Male emigration was also predominant in Portugal (Brettell, Men Who Migrate). Reher, Pombo, and Nogueras (España) also used the sex ratio to analyze male emigration in the late nineteenth century.

" For example, Northern Spaniards were already the largest regional group in late eighteenth-century Buenos Aires (Socolow, Merchants of Buenos Aires), and remained so in the mid-nineteenth century (Moya, Cousins and Strangers, table 1).

${ }^{4}$ The variable will take a range of values, from one when inheritance was totally partible, to four for total impartibility (this is a rough indicator because of enormous differences in the inheritance systems within provinces). I gratefully acknowledge Vicente Pérez Moreda for sharing his data with me.
} 
landowner (some employers were in turn employed by others, particularly in the north), and although 1920 might seem remote in time from 1911/13, it seems safe to assume that the structure of land ownership in Spain did not change much in the interim.

Results of the cross-sectional analysis for 1911/13 are presented in Table 4. Both regressions have high explanatory power, as judged by the $R^{2} \mathrm{~s}$, but the significance of the coefficients vary. Regression 2 shows the main determinants of provincial emigration. Regression 1 includes variables with very low levels of significance. Prior demographic growth, for example, displays a positive but very weak relationship with emigration. Assertions made by historians about the strong effect of demographic growth on emigration are confirmed neither at the provincial level nor in the aggregate time-series analysis (see Table 2). The relation between land tenure and emigration is not significant either, though it does have the expected sign: the more wage laborers in each province, the fewer landowners-and, hence, the lower the rate of external emigration.

The inverse correlation between the share of the active population employed in agriculture and emigration supports the view that population employed in agriculture is a plausible indicator of economic backwardness, which in turn inhibits emigration. Labor productivity in agriculture is statistically significant in both regressions and is negatively correlated with emigration, supporting the hypothesis that people in areas of high labor productivity were likelier to stay. According to Regression 2 a one-standard-deviation increase in agricultural output per worker could depress the rate of gross emigration by 2.78 per thousand $(0.24 \cdot-11.597=-2.78)$.

The results presented in Table 4 also suggest that an increase in agricultural wages gave many aspiring emigrants the means to do so-and, contrariwise, that low wages constrained emigration from many Spanish provinces. According to Regression 2, a wage increase equivalent to one standard deviation would increase the rate of provincial emigration by more than 2.2 per thousand $(0.25 \cdot 8.868=2.22)$. Although the decision to emigrate might be based on a rational assessment of a future income stream, the timing of emigration might depend on recent changes in wages. The negative relationship between agricultural productivity and emigration seems to indicate that rural incomes played very different roles in rich and poor provinces: in the former, high incomes discouraged emigration, while in the latter a substantial increase in wages facilitated it.

Results for the urbanization variable support the view that, for many Spanish provinces, internal migration provided a clear alternative to emigration overseas. Historians who emphasize the role of cities "pulling" migrants from the countryside appear to have a point. According to Regression 2, an increase in the urbanization variable equivalent to one standard deviation 
TABLE 4

REGRESSION RESULTS: PROVINCIAL EMIGRATION RATES, 1911/13

\begin{tabular}{lcccc}
\hline & & & & \\
& $(1)$ & $(2)$ & Mean & $\begin{array}{c}\text { Std. } \\
\text { Dev. }\end{array}$ \\
\hline Dependent variable & & & 9.55 & 9.79 \\
Constant & 135.077 & 116.783 & & \\
& $(2.943)^{* * *}$ & $(2.599)^{* * *}$ & & \\
Rate of natural increase (lagged $t-20)$ & 0.194 & & -0.77 & 0.54 \\
& $(0.106)$ & & & \\
Change in literacy, 1887-1910 & 15.802 & 17.003 & 0.34 & 0.18 \\
& $(3.400)^{* * *}$ & $(3.473)^{* * *}$ & & \\
Share of labor force in agriculture, 1910 & -12.217 & -10.538 & 4.26 & 0.18 \\
& $(-2.016)^{*}$ & $(-1.780)^{*}$ & & \\
Changes in agricuitural wages, 1896-1908 & 9.429 & 8.868 & 0.21 & 0.25 \\
& $(3.070)^{* * *}$ & $(3.060)^{* * *}$ & & \\
Migratory tradition (female/male ratio in & 52.729 & 49.437 & -0.05 & 0.10 \\
50-60 age group, 1887) & $(9.309)^{* * *}$ & $(8.919)^{* * *}$ & & \\
Land tenure system (percent of wage & -4.088 & & -0.34 & 0.25 \\
laborers in agricultural labor force, 1920) & $(-0.961)$ & & & \\
Agricultural output per worker, 1909/13 & -13.093 & -11.597 & 6.66 & 0.24 \\
& $(-2.900)^{* * *}$ & $(-2.585)^{* * *}$ & & \\
Urbanization, 1910 & -4.066 & -5.013 & -1.58 & 0.81 \\
& $(-2.374)^{* *}$ & $(-3.327)^{* * *}$ & & \\
Degree of impartible inheritance & -2.325 & -2.083 & & \\
$R^{2}$ & $(-2.255)^{* *}$ & $(-2.184)^{* *}$ & & \\
$R^{2}$ (adjusted) & 0.745 & 0.710 & & \\
S.E. of regression & 0.681 & 0.660 & & \\
$F$-statistic & 5.639 & 5.703 & & \\
$N$ & 11.712 & 14.364 & & \\
\hline
\end{tabular}

= Significant at the 10 percent level.

** = Significant at the 5 percent level.

**** = Significant at the 1 percent level.

- Gross emigration in 1911/13 per thousand population in province, 1910.

Notes: $t$-statistics are in parentheses. Independent variables are expressed in logs. Standard errors and covariance are White heteroskedasticity-consistent.

Sources: See the Appendix.

reduced the rate of provincial emigration by 4.1 per thousand, a much stronger impact than in the case of Italy. ${ }^{\text {so }}$

Changes in literacy between 1887 and 1910 turn out to be one of the most powerful variables in explaining provincial emigration rates. According to Regression 2, an increase in literacy equivalent to one standard deviation produced a change in the gross rate of emigration of 3.1 per thousand. In provinces where literacy was growing quickly, potential emigrants appear to have enjoyed falling information costs, such that the economic and social networks that facilitated emigration developed more easily. This result is

\footnotetext{
${ }^{30}$ Note, though, that in Italy the negative effect was greater in the north than in the south (Hatton and Williamson, Age of Mass Migration, table 6.6).
} 
particularly striking when compared to the case of Italy. In explaining the rates of emigration across Italian provinces with a very similar model, Hatton and Williamson find that levels of literacy had no discernible effect on emigration rates; this casts doubt on the view that literacy (either as a proxy for knowledge about foreign markets or as a valuable asset in the labor market) was the key which unlocked massive emigration. ${ }^{51}$ Since they also find that emigration traditions (proxied by the lagged emigration rate) had a small effect in Italy, it is difficult to understand how potential Italian emigrants knew about opportunities abroad. The right variable to use might be either return migration (which they do not include) or past changes in literacy rates, which allowed more potential emigrants to increase their knowledge of opportunities abroad. In some Spanish provinces, increases in literacy probably substituted for lower levels of past emigration, as a way of providing information about opportunities abroad.

The importance of a migratory tradition in the Spanish case is confirmed by the strong significance of the variable intended to capture continuity in emigration, that is, the gender ratio for $1887 . .^{52}$ According to Regression 2, an increase in this variable equivalent to one standard deviation caused the rate of gross emigration to rise by more than 5 per thousand. The pioneer emigrants of the 1850 s and the 1860 s, though few in number, seem to have been very influential..$^{53}$

Finally, the variable representing inheritance systems is highly significant. In contrast to Ireland and some regions in Germany, in Spain people from regions where inheritance was predominantly impartible appear to have been less prone to emigrate than those from regions where each sibling received a small part of the inheritance. This small part granted by law apparently permitted more people to afford the cost of emigration. Once more this seems to confirm the hypothesis that emigration from Spain was incomeconstrained.

In order to test whether determinants of regional emigration changed over time, I have carried out a pooled cross-section regression of gross emigration out of the 49 Spanish provinces in $1888 / 90$ and $1911 / 13$. Table 5 presents the determinants of provincial emigration between the two dates, using a panel data set of 98 observations. Unfortunately, the number of variables has been reduced due to gaps in the data. Yet Regression 1 in Table 5 displays

\footnotetext{
${ }^{51}$ Ibid., p. 113; they obtain similar results for Ireland in chap. 5. However, they use the level of literacy in a year, not changes in the literacy rates over time as in this article. For England and Wales, too, Baines (Migration, appendix 7) fails to find a significant relation between emigration and literacy.

$\$ 2$ The positive sign indicales that the larger the number of females relative to males in each province (a proxy for past emigration), the higher the rate of current emigration.

${ }^{53}$ Galicians, Basques, Asturians, and Catalans were the largest regional groups in 1855 (Moya Cousins and Strangers, table 1). Benito Hortelano, an immigrant of the $1850 \mathrm{~s}$, remembers in his memoirs (Memorias) that these regional groups already accounted for the majority of Spaniards living in Buenos Aires.
} 
TABLE 5

POOLED REGRESSION ESTIMATES: PROVINCIAL EMIGRATION RATES, 1888/90 AND $1911 / 13$

\begin{tabular}{|c|c|c|c|c|}
\hline & (1) & (2) & Mean & $\begin{array}{l}\text { Std. } \\
\text { Dev. }\end{array}$ \\
\hline Dependent variable & & & 6.68 & 8.42 \\
\hline Constant & $\begin{array}{l}11.223 \\
(1.914)^{*}\end{array}$ & $\begin{array}{l}18.661 \\
(4.017)^{* * *}\end{array}$ & & \\
\hline Changes in literacy, $1877-87$ and $1887-1910$ & $\begin{array}{l}12.991 \\
(4.280)^{* * *}\end{array}$ & & 0.23 & 0.19 \\
\hline Urbanization, 1887 and 1910 & $\begin{array}{l}-1.258 \\
(-1.760)^{*}\end{array}$ & & -1.64 & 0.83 \\
\hline Agricultural output per worker, $1886 / 90$ and $1909 / 13$ & $\begin{array}{l}-2.026 \\
(-2.214)^{* *}\end{array}$ & $\begin{array}{l}-2.569 \\
(-3.447)^{* * *}\end{array}$ & 6.32 & 0.70 \\
\hline $\begin{array}{l}\text { Migratory tradition (female/male ratio in 50-60 } \\
\text { age group, } 1877 \text { and } 1887 \text { ) }\end{array}$ & $\begin{array}{l}44.555 \\
(10.218)^{* * *}\end{array}$ & $\begin{array}{l}30.01 \\
(4.955)^{* * *}\end{array}$ & -0.04 & 0.10 \\
\hline Time dummy & $\begin{array}{l}2.778 \\
(2.255)^{* *}\end{array}$ & & & \\
\hline Time dummy interacting with changes in literacy & & $\begin{array}{l}15.281 \\
(3.374)^{* * *}\end{array}$ & & \\
\hline Time dummy interacting with urbanization & & $\begin{array}{l}-3.037 \\
(-2.576)^{* *}\end{array}$ & & \\
\hline $\begin{array}{l}\text { Time dummy interacting with agricultural output per } \\
\text { worker }\end{array}$ & & $\begin{array}{l}-0.786 \\
(-2.834)^{* * *}\end{array}$ & & \\
\hline Time dummy interacting with migratory tradition & & $\begin{array}{l}-23.638 \\
(-2.559)^{* *}\end{array}$ & & \\
\hline$R^{2}$ & 0.601 & 0.655 & & \\
\hline$R^{2}$ (adjusted) & 0.580 & 0.633 & & \\
\hline S.E. of regression & 5.457 & 5.101 & & \\
\hline F-statistic & 27.805 & 28.891 & & \\
\hline$N$ & 98 & 98 & & \\
\hline
\end{tabular}

- Significant at the 10 percent level.

$* *=$ Significant at the 5 percent level.

*** = Significant at the 1 percent level.

- Rate of gross emigration in $1888 / 90$ and $1911 / 13$ per thousand population in 1887 and 1910 , respectively, in each province.

Notes: t-statistics are in parentheses. Independent variables are expressed in logs. White heteroskedasticity-consistent standard errors and covariance.

Sources: See the Appendix.

some interesting results. The time variable, designed to capture differences between the nineteenth and twentieth centuries, is positive and significant. Over time, increases in literacy became a powerful force driving emigration; conversely, urbanization seems to have slowed it. The urban variable is statistically less significant here than in 1911/13, and the coefficient is smaller, suggesting that the lower rate of urbanization in late nineteenthcentury Spain had a weaker effect on emigration. Labor productivity in agriculture is again negative and significant. ${ }^{54}$ An increase in the rate of

\footnotetext{
34 The share of labor force employed in agriculture, included in preliminary tests, attained a very low level of significance but a negative sign, as in Table 4.
} 
urbanization and in agricultural output per worker equivalent to one standard deviation appears to have reduced the rate of emigration by 1.0 and 1.4 per thousand, respectively. Increases in literacy rates equivalent to one standard deviation would indicate a subsequent increase in the province's rate of emigration over time of 2.5 per thousand. For the case of Spain, the importance of literacy in relaxing the information constraint is thereby confirmed. Finally, migratory tradition again yields the strongest and most significant results. An increase in this variable equivalent to one standard deviation apparently increased the gross rate of provincial emigration by 4.8 per thousand. This suggests that historians should turn to the first half of the nineteenth century and find out why, when, and how some Spanish provinces established early relations with ex-colonies in the New World, while others did not.

Regression 2 includes various interaction variables. (Only those variables that turned out to be significant are reported.) Neither changes in literacy nor rates of urbanization became significant when allowed to interact with the time dummy. This suggests that literacy and urbanization may have been important forces behind emigration in the twentieth century but were weaker in the nineteenth. Both literacy and urbanization rates were very low in 1887 , but they increased over the first decade of the twentieth century. The time dummies interacting with these variables help to explain the acceleration of emigration from many Spanish provinces after 1900 . Agricultural output per worker and migratory tradition are once again highly significant when allowed to interact with the time dummies. Although these forces were relevant on the eve of the First World War, they were even more important in the long run and show strong continuity with the situation in the nineteenth century.

\section{CONCLUSIONS}

Spanish emigrants were not so different from their counterparts in the rest of Southern Europe, except in their preference for Latin America, in the low rates of emigration in the late nineteenth century, and in the large variations in regional emigration rates. Culture, language, and old colonial links, not policy, seem to explain the Spanish preference for Latin American countries. Given the advantage of the language, Spanish emigrants-who were not as illiterate as contemporaries believed - had more to gain in Argentina or Cuba than in the United States. Cuba might also have acted as a substitute for the United States for those emigrants heading towards North America. They preferred to live in a Spanish colony, or even an ex-colony, and consequently they never tried their fortune in the U.S. market. Segmentation of the international labor market thus dominated Spanish emigration to a greater extent than in Italy. 
Contrary to conventional wisdom, and in sharp contrast with the Italian case, Spanish emigration during the period 1880 to 1914 was income-constrained. Rising income per capita at home was positively associated with emigration because it allowed people to finance the move more easily. The same finding is supported by results presented at the provincial level. Spanish emigration from many provinces had long been constrained by low wages, such that wage increases allowed a larger sector of the population to fund their own emigration.

The removal of obstacles to information flows through increases in literacy turns out to be a significant explanation for differences in regional emigration rates, in contrast with the case of Italy. Literacy was more important in Spain probably because it substituted for lower levels of past emigration. Thus for many Spanish provinces, particularly in the interior and the south, poverty and ignorance were real constraints on emigration. In contrast with other European countries, people from regions where the inheritance system was predominantly impartible were less prone to emigrate than those from regions where each sibling received a small part of the estate. Again this effect operated because emigration was income constrained, the sale of inherited goods or properties producing the funds required by poor emigrants to leave the country.

Demographic forces were unusually weak in Spain after the 1880 s, both over time and across regions, but Spanish emigrants responded to wage differentials and migratory traditions in the same way as other European emigrants. In particular, the importance of a migratory tradition behind the persistent patterns of regional emigration stands out. Spanish emigration can be represented as a case of path dependency, but the question remains why some provinces had constructed a path to follow, while others had not. The answer, which seems to lie in the middle decades of the nineteenth century, is a matter for deeper and more comprehensive historical investigation.

\section{Appendix: Notes on Data}

Emigration data come from Instituto Geográfico y Estadistico, Estadistica de la emigración y de la inmigración de España, 1882-1890 (Madrid, Dirección General del Instituto Geográfico y Estadístico, 1891) and Estadística de la emigración e inmigración de España, 1907-1913 (Madrid, Ministerio de Instrucción Pública y Bellas Artes, 1914), as revised and recalculated in Sánchez-Alonso, Causas, chap. 2.

Population data come from Censo de la población de España según el empadronamiento hecho en la Peninsula y las islas adyacentes en 31 de diciembre de 1887 (Madrid, Instituto Geográfico y Estadístico, 1891-92), and Censo de la población de España segtín el empadronamiento hecho en la Península y las islas adyacentes en 31 de diciembre de 1910 (Madrid, Instituto Geográfico y Estadístico, 1913-19).

Rates of natural population increase in 1887 come from Reher, Pombo, and Nogueras, España, as does the female/male ratio for the 50-to-60 age group in 1887 . The same ratios 
for 1877 were calculated from Censo de la población de España segin el empadronamiento hecho en la Peninsula y las islas adyacentes en 31 de diciembre de 1877 (Madrid, Instituto Geográfico y Estadístico, 1883/84).

Nominal agricultural wages for 1896 are annual wages in 1896-97 for agricultural workers in towns up to 6,000 inhabitants: they are taken from Estadistica de la emigración e inmigración de España, 1896-1900 (Madrid, Instituto Geográfico y Estadístico, 1903, pp. xlvii-xlix ). For 1908 they are annual wages of men, women and children working in agriculture: they are taken from Preparación de las bases para un proyecto de ley de accidentes de trabajo en la agricultura (Madrid, Instituto de Reformas Sociales, 1914). Changes in agricultural wages between 1896 and 1908 were computed as the ratio of 1908 to 1896 wages.

The share of labor force in agriculture in 1910 is the ratio of the active male population employed in agriculture over total active population in each province: see Simpson, "Spanish Agricultural Production."

Agricultural output per worker is the average for the years 1909/13 and 1886/90 (according to population in 1910 and 1887) as calculated by Simpson, "Spanish Agricultural Production" and "Producción agraria," respectively.

The ratio of agricultural workers to total agricultwal labor force in 1920 , used as a proxy for land tenure systems, derives from Rodriguez Labandeira Trabajo rural, pp. $440-41$.

Rates of urbanization are the ratio of population living in towns (of 5,000 inhabitants and above) to total population in each province in 1887 and 1910: they are taken from Luna Rodrigo, "Población urbana."

Literacy refers to population aged seven and above able to read (though not necessarily to write): data are taken from Censos de población, 1877, 1887, and 1910. Changes in literacy rates between 1877 to 1887 and 1887 to 1910 are the ratio of literacy levels of 1887 to 1877 and of 1910 to 1887 , respectively.

\section{REFERENCES}

Arango, Joaquin. "La modernización demográfica de la sociedad española." In La economía española en el siglo XX. Una perspectiva histórica, edited by Jordi Nadal, Albert Carreras, and Carles Sudriá, 201-07. Barcelona: Ariel, 1987.

Baganha, Maria I. Portuguese Emigration to the United States, 1820-1930. New York: Garland, 1990.

Baily, Samuel L. "Italian Immigrants in Buenos Aires and New York." American Historical Review 88, no. 2 (1983): 281-305.

Baines, Dudley E. Migration in a Mature Economy: Emigration and Internal Migration in England and Wales, 1861-1900. Cambridge: Cambridge University Press, 1985.

Ballesteros, Esmeralda. "Una estimación del coste de la vida en España, 1861-1936." Revista de Historia Económica 15, no. 2 (1997): 363-95.

Barreiro Mallón, Baudilio. "Ritmo, causas y consecuencias de la emigración asturiana a América, 1700-1900." In Emigración española y porruguesa a América, edited by Antonio Eiras Roel, 73-88. Alicante: Instituto de Cultura Juan Gil Albert, 1991.

Botella, Cristobal. El problema de la emigración. Madrid: Gráficas Madrid, 1888.

Brettell, Caroline B. Men Who Migrate, Women Who Wait. Population and History in a Portuguese Parish. Princeton: Princeton University Press, 1986.

Cinel, Dino. "Land Tenure Systems, Return Migration and Militancy in Italy." Journal of Ethnic Studies 12, no. 3 (1984): 55-74.

Cipolla, Carlo. Literacy and Development in the West. Baltimore: Penguin Books, 1969. 
Consejo Superior de Emigración. La emigración española transoceánica, 1911-1915. Madrid: Imprenta T. Minuesa, 1916.

Cortés Conde, Roberto. La economía argentina en el largo plazo. (Siglos XIXYXX). Buenos Aires: Ed. Sudamericana, 1997.

Costa Leite, Joachim. "Portuguese Emigration: The Influence of Land and Family (18551914)." Unpublished manuscript, 1987.

Faini, Riccardo, and Alessandra Venturini. "Italian Emigration in the Pre-War Period." In Migration and the International Labor Market, 1850-1939, edited by Timothy J. Hatton and Jeffrey G Williamson, 72-90. London: Routledge, 1994.

Fernández de Pinedo, Emiliano. "Los movimientos migratorios vascos, en especial hacia América." In Españoles hacia América. La emigración en masa, 1880-1930, edited by Nicolás Sánchez-Albornoz, 105-23. Madrid: Alianza, 1988.

Fitzpatrick, David. Irish Emigration, 1801-1921. Dublin: Dungalgen Press, 1984.

Gabaccia, Donna R. "Migration and Peasant Militance: Western Sicily, 1880-1914." Social Science History 8, no. 2 (1984): 67-80.

Gould, John D. "European Inter-Continental Emigration, 1815-1914: Patterns and Causes." Journal of European Economic History 8, no. 3 (1979): 593-679.

."European Inter-Continental Emigration: The Role of 'Diffusion' and 'Feedback'." Journal of European Economic History 9, no. 2 (1980): 267-317.

Guinnane, Timothy W. The Vanishing Irish: Households, Migration and the Rural Econormy in Ireland, 1850-1914. Princeton: Princeton University Press, 1997.

Hatton, Timothy J, and Jeffrey G. Williamson. The Age of Mass Migration. Causes and Economic Impact. New York: Oxford University Press, 1998.

Hernández Garcia, Juan. La emigración de las Islas Canarias en el siglo XIX. Las Palmas: Cabildo Insular de Gran Canaria, 1981.

Hortelano, Benito. Memorias de Benito Hortelano. Madrid: Espasa-Calpe, 1936.

Klein, Herbert S. "La integración social y económica de los inmigrantes españoles en Brasil." Revista de Historia Económica 7, no. 2 (1989): $439-60$.

Lisón Tolosana, Carmelo. "The Ethics of Inheritance." In Mediterranean Family Structures, edited by J.G. Peristiany, 305-17. Cambridge: Cambridge University Press, 1976.

López Taboada, Xoan. Economía e población en Galicia. La Coruña: Rueiro, 1979.

Luna Rodrigo, Gloria. "La población urbana en Espanta, 1860-1930." Boletín de la Asociación de Demografía Histórica 6, no. 1 (1988): 25-69.

Machado, Antonio. Campos de Castilla. Madrid: Austral, 1912.

Malefakis, Edward. Agrarian Reform and Peasant Revolution in Spain: Origins of the Civil War. New Haven and London: Yale University Press, 1970.

Mikelarena, Fernando. "Los movimientos migratorios interprovinciales en España entre 1877 y 1930: áreas de atracción, áreas de expulsión, periodización cronológica y cuencas migratorias." Cradernos Aragoneses de Economia 3, no. 2 (1993): 213-40.

Moya, José C. Cousins and Strangers: Spanish Immigrants in Buenos Aires, 1850-1930. Berkeley: University of California Press, 1998.

Nadal, Jordi. La población española. Siglos XVI al XX. Barcelona: Ariel, 1973.

Nicolau, Roser. "La población." In Estadísticas Históricas de España. Siglos XIX y XX, edited by Albert Carreras, 49-90. Madrid: Fundación Banco Exterior, 1989.

Ó Gráda, Cormac. "Primogeniture and Ultimogeniture in Rural Ireland." Journal of Interdisciplinary History 10, no. 3 (1980): 491-97.

Pérez Moreda, Vicente. "El proceso de alfabetización y la formación de capital humano en España." Papeles de Economía 73 (1997): 243-52.

. "La evolución demográfica española en el siglo XIX (1797-1930): tendencias generales y contrastes regionales." In La popolazione italiana nell 'Ottocento. Bologna: 
Clueb, 1985.

Pildain Salazar, M² Pilar. Ir a América. La emigración vasca a América (Guipuzcoa 1840 1870). San Sebastián: Caja de Ahorros Municipal de San Sebastián, 1984.

Prados de la Escosura, Leandro. "Output and Expenditure in Spain, 1850-1980: New GDP Series." Unpublished manuscript, 1999.

Ravenstein, Edward G. "The Laws of Migration II." Journal of the Royal Statistical Society 52 (June 1889): 241-301.

Reher, David S. "La teoría del capital humano y las realidades de la historia." Papeles de Economia 73 (1997): 254-61.

Reher, David S., $\mathbf{M}^{\mathrm{P}}$ Nieves Pombo, and Beatriz Nogueras. España a la luz del censo de 1887. Madrid: INE, 1993.

República de Cuba. Secretaria de Hacienda. Inmigración y movimiento de pasajeros. La Habana: Secretaría de Hacienda, Sección Estadísticas, 1902-1932.

Rodriguez Labandeira, José. El trabajo rural en España (1876-1936). Madrid: Anthropos, Ministerio de Agricultura, 1991.

Rosoli, Gianfausto (ed.). Un secolo di emigrazione italiana. 1876-1976. Roma: Centro Studi Emigrazione, 1978.

Rowland, Robert. "Emigración, estructura y región en Portugal (siglos XVI-XIX)." In Emigración española y portuguesa a América, edited by Antonio Eiras Roel, 137-46. Alicante: Instituto de Cultura Juan Gil Albert, 1991.

Sánchez-Alonso, Blanca. "European Emigration in the Late Nineteenth Century: The Paradoxical Case of Spain." Economic History Review 53, no. 2 (2000): 309-30.

. Las cansas de la emigración española, 1880-1930. Madrid: Alianza, 1995.

. La inmigración española en Argentina. Siglos XIXY XX. Gijón: Ed. Júcar-Fundación Archivo de Indianos, 1992.

Simpson, James. Spanish Agriculture: The Long Siesta, 1765-1965. Cambridge: Cambridge University Press, 1995.

."Spanish Agricultural Production and Productivity." In The Economic Development of Spain Since 1870, edited by Pablo Martin Aceña and James Simpson, 181-220. New York: Elgar, 1995.

."La producción agraria en 1886-1890: un enfoque de la agricultura española del siglo XDX." Unpublished manuscript, 1986.

Socolow, Susan M. The Merchants of Buenos Aires, 1778-1810. Cambridge: Cambridge University Press, 1978.

Soldevilla, Consuelo. "La emigración de Cantabria a América: un análisis regional." In Emigración española y portugiesa a América, edited by Antonio Eiras Roel, 89-98.

Alicante: Instituto de Cultura Juan Gil Albert, 1991.

Sori, Ercole. L'emigrazione italiana dall 'Unita alla seconda guerra mondiale. Bologna: Il Mulino, 1979.

Taylor, Alan M. "Mass Migration to Distant Southern Shores. Argentina and Australia, 1870-1939." In Migration and the Intermational Labor Market, 1850-1939, edited by Timothy J. Hatton and Jeffrey G. Williamson, 91-115. London: Routledge, 1994.

Thomas, Brinley. Migration and Economic Growth: A Study of Great Britain and the Atlantic Economy. Cambridge: Cambridge University Press, 1954.

Tortella, Gabriel. "Agriculture: A Slow-Moving Sector, 1830-1935." In The Economic Modernization of Spain, 1830-1930, edited by Nicolás Sánchez-Albornoz, 42-62. New York: New York University Press, 1987.

Vandellós, José Antonio. "La richesse et le revenu de la Péninsule Ibérique." Metron 5, no. 4 (1925): 151-86.

Vázquez González, Alejandro. "La emigración gallega a América. Migrantes, transportes y remesas." In Españoles hacia América. La emigración en masa, 1880-1930, edited 
by Nicolás Sánchez-Albornoz, 80-105. Madrid: Alianza, 1988.

Vilar, Juan Bautista. Emigración española a Argelia (1830-1900). Colonización hispánica de la Argelia francesa. Madrid: CSIC, 1975.

Williamson, Jeffrey G "The Evolution of Global Labour Markets Since 1830: Background Evidence and Hypotheses." Explorations in Economic History 32, no. 2 (1995): 141-97.

"The Evolution of Global Labor Markets Since 1830: Background Evidence and Hypotheses." Revision of "Appendix 1: Nominal Wage, Cost of Living and Real Wage Series." Unpublished manuscript, 1996. 